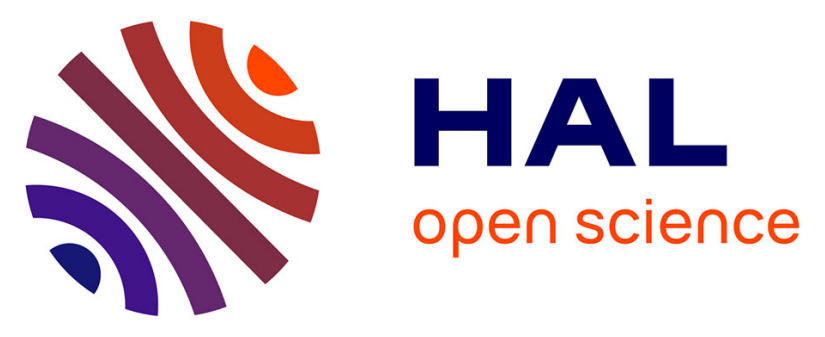

\title{
Polymerized bonding agents and the differentiation in vitro of human pulp cells into odontoblast-like cells
} Imad About, Jean Camps, Anne-Sophie Burger, Thimios A Mitsiadis, William T Butler, Jean-Claude Franquin

\section{- To cite this version:}

Imad About, Jean Camps, Anne-Sophie Burger, Thimios A Mitsiadis, William T Butler, et al.. Polymerized bonding agents and the differentiation in vitro of human pulp cells into odontoblast-like cells. Dental Materials, 2005, 21 (2), pp.156-163. 10.1016/j.dental.2004.02.011 hal-03552378

\section{HAL Id: hal-03552378 https://hal.science/hal-03552378}

Submitted on 2 Feb 2022

HAL is a multi-disciplinary open access archive for the deposit and dissemination of scientific research documents, whether they are published or not. The documents may come from teaching and research institutions in France or abroad, or from public or private research centers.
L'archive ouverte pluridisciplinaire HAL, est destinée au dépôt et à la diffusion de documents scientifiques de niveau recherche, publiés ou non, émanant des établissements d'enseignement et de recherche français ou étrangers, des laboratoires publics ou privés.

\section{(ㅇ)(1) $\$$}

Distributed under a Creative Commons Attribution - NonCommercial - NoDerivatives| 4.0 


\title{
Polymerized bonding agents and the differentiation in vitro of human pulp cells into odontoblast-like cells
}

\author{
Imad About ${ }^{a, *}$, Jean Camps ${ }^{a}$, Anne-Sophie Burger ${ }^{a}$, Thimios A. Mitsiadis ${ }^{a}$, \\ William T. Butler ${ }^{\mathrm{b}}$, Jean-Claude Franquin ${ }^{\mathrm{a}}$
}

\author{
a'Laboratoire IMEB, Faculté d'Odontologie, Université de la Méditerranée, 27 Boulevard Jean Moulin, \\ 13385 Marseille Cedex 5, France \\ ${ }^{\mathrm{b}}$ University of Texas, Health Sciences Center, Dental Branch, Houston, TX, USA
}

\author{
KEYWORDS \\ Human odontoblast \\ differentiation; Dentin \\ bonding
}

Summary Objectives: Odontoblasts are highly differentiated post-mitotic cells, which under pathological conditions such as carious lesions and dental injuries may degenerate and be replaced by other pulp cells. We have recently shown that this physiological event can be reproduced in an in vitro assay system, but is highly modified by the presence of unpolymerized resinous monomers. Our hypothesis was that the photopolymerization of the monomers in the bonding agents might abolish these negative effects. The purpose of this study was to evaluate the effects of polymerized dentin bonding agents, through dentin slices, on odontoblast differentiation in vitro.

Methods: Pulp cells were obtained from human third molars. They were used to study the effects of four dentin bonding agents through $0.7 \mathrm{~mm}$ dentin slices which served as a barrier between the bonding agents and the culture medium. The media containing the bonding agents' extracts were added at non-toxic concentrations onto the cultured cells. Immunohistochemistry was performed to study the differentiation of pulp fibroblasts into odontoblasts under these conditions by evaluating the expression of several odontoblast specific genes.

Results: Pulp fibroblasts cultivated under these conditions synthesized type I collagen, osteonectin, dentin sialoprotein and nestin at the same level as in control cultures. Moreover, pulp cells synthesized a mineralized nodular extracellular matrix. Expression of these proteins was higher in the cells contributing to the nodule formation. In addition, except nestin, all these proteins were expressed in the mineral nodules.

Significance: This work shows the lack of effects of photopolymerized bonding agents, through dentin slices, on cytodifferentiation of secondary odontoblasts.

\section{Introduction}

Dental pulp cells and dentin can be seen as an entity called pulp-dentin complex. ${ }^{1}$ This means that factors affecting the dentin may have consequent 
effects on the dental pulp. This is of prime importance during dental restorative procedures, since the preparation of the cavity and its subsequent filling by different materials may harm the dental pulp.

Pulp reactions to restorative procedures are variable. Although it is possible to prepare cavities in the dentin with no pulpal inflammation or formation of reparative dentin, ${ }^{2}$ numerous studies showed that deep cavity preparation causes death of odontoblasts which are then replaced by secondary odontoblasts prior to secretion of reparative dentin. ${ }^{1}$ Subsequently, the restorative material, placed onto the dentin cavity, may also produce a pulp reaction due to dentin permeability. The structure of dentin allows the diffusion of small molecules released from the material, as well as bacterial diffusion toward the pulp. It is well established that uncured monomers leaching from composites can diffuse through dentin and reach the pulp within minutes after placement of a restorative material, inducing an initial pulp reaction. $^{3}$ At subsequent time periods, the bacterial leakage around the margins of a definitive restoration is the principal reason of pulp pathology observed under a restorative material. ${ }^{4,5}$

Many in vitro studies have shown the undeniable effects of the restorative materials, used as direct pulp capping agent or restorative material, on dental pulp cells. The resinous monomers are cytotoxic to pulp fibroblasts and their ID50 ranges from $10^{-5}$ to $10^{-2} \mathrm{M}^{6}$ The degree of cytotoxicity depends on the concentration of the material used and the monomers may have synergistic or antagonistic cytotoxic effects. ${ }^{7}$ At non-toxic concentrations, the monomers may reduce the mitochondrial activity of pulp macrophages ${ }^{8}$ and suppress interleukin-1 and tumor necrosis factor secretion. ${ }^{9}$ They may also cause T lymphocytes immunosuppression ${ }^{10}$ and complement activation ${ }^{11}$ thus playing an important role in pulp response.

Direct pulp capping involves the placement of the filling material directly onto the pulp core, which is partly amputated of its odontoblastic layer. During pulp healing, pulp cells may differentiate into odontoblast-like cells, which subsequently start to secrete the matrix of the reparative dentin. ${ }^{12}$ The mechanisms leading to odontoblast differentiation and reparative dentin secretion, during dentin wound healing, are not completely understood. ${ }^{13-15}$ Calcium hydroxide and mineral trioxide aggregate are well established direct capping agents. ${ }^{16}$ More recently, composites have been proposed on the basis of animal experiments, ${ }^{17}$ but controversy remains concerning the safety of the direct pulp capping with resinous materials. Indeed, some authors showed irreversible pulpal alterations after direct exposure to composites. ${ }^{18}$ In a previous in vitro study, we showed that the direct application of uncured monomers, at non-toxic concentrations, interfered with the phenomena that lead to odontoblast differentiation and dentin secretion. ${ }^{19}$

In coronal restorations, pulpal clearance associated with dentin permeability decreases the pulpal concentrations in monomers, but non-toxic concentrations of monomers still have biological effects. For example, it has been shown that a long exposure of THP-1 human monocyte-macrophages to a sub-lethal concentration of HEMA diluted to $0.1 \mathrm{mM}$ modifies their mitochondrial activity, proliferation and protein content, ${ }^{20}$ while sub-toxic concentrations of HEMA induce changes in cell phospholipid metabolism in vitro. ${ }^{21}$ Under these conditions, on the basis of the authors' first study, ${ }^{19}$ one may suppose that these non-toxic concentrations may also interfere with the cytodifferentiation of secondary odontoblasts.

Using an accepted in vitro model of human dentin production, ${ }^{15}$ this study tested, in vitro, the hypothesis that photopolymerization of monomers in the bonding agents applied to dentin slices, may abolish their negative effects on the differentiation of human pulp cells into odontoblasts. This is of prime importance in restorative dentistry particularly in deep cavity restorations where odontoblastic differentiation from pulp fibroblasts is a critical step in hard tissue secretion and pulp healing.

\section{Material and methods}

Reagents. All materials used for culture media preparation were purchased from Gibco BRL (Life Technologies, Inc., Grand Island, NY, USA) unless otherwise specified. Minimum essential medium (MEM) was supplemented with $10 \%$ fetal bovine serum, $2 \mathrm{mM}$ glutamine, $100 \mathrm{Ul} / \mathrm{ml}$ penicillin, $100 \mu \mathrm{g} / \mathrm{ml}$ streptomycin (Biowhittaker, Gagny, France) and $0.25 \mu \mathrm{g} / \mathrm{ml}$ amphotericin B (Fungizone ${ }^{\circledR}$ ).

Antibodies. Polyclonal antibodies against type I collagen were purchased from Southern Biotechnology Associates Inc. (Birmingham, AL, USA). Monoclonal antibody to osteonectin was obtained from Takara Biochemicals (Takara Shuzo Co. Ltd, Shiga, Japan). Preparation and characterization of the polyclonal antibodies against dentin sialoprotein (DSP) have been already described. 22-24 Preparation and characterization of the rabbit 
anti-nestin antiserum, which is raised against the c-terminal region of rat nestin, has already been described. ${ }^{25}$ This antiserum specifically identifies nestin in immunohistochemistry and in Western blots $^{26,27}$ and its specificity to human odontoblasts has been detailed. ${ }^{28}$

Teeth. For pulp cell cultures, normal immature third molars freshly extracted for orthodontic reasons from 16- to 18-year-old patients were used after obtaining theirs and their parents' informed consents. Additionally, for the preparation of dentin slices, 80 healthy human third molars freshly extracted were stored at $4{ }^{\circ} \mathrm{C}$ in saline solution and used within $2 \mathrm{~h}$ of collection.

Preparation of the dentin slices. Dentin slices were prepared as described previously. ${ }^{29,30}$ Briefly, the dentin slices were prepared from third molars using a low speed diamond saw (Isomet, Buehler Ltd, Lake Bluff IL, USA) with water coolant. The dentin sections were from areas adjacent to the pulp chamber, but they showed no evidence of inclusion of a pulpal horn. The dentin slices had a thickness of $0.7 \pm 0.05 \mathrm{~mm}$. To create a constant dentin surface area the coronal side of the dentin slice was attached with a non-cytotoxic cyanoacrylate glue to a Plexiglas ring $1 \mathrm{~cm}$ thick, $2 \mathrm{~cm}$ in diameter with a hole of $0.8 \mathrm{~cm}$ in its centre. This permitted the authors to reduce and standardise the exposed dentin surface area to $50.24 \mathrm{~mm}^{2}$.

Simulation of pulpal pressure. The Plexiglas rings were removed and placed in a special device used to simulate pulsatile pulpal pressure. This device has already been described. ${ }^{31}$ Briefly, the Plexiglas device was used to maintain the dentin slice in such a position that the culture medium slightly touches its pulpal side, while the coronal side is open to the atmosphere. The lower chamber $(4 \mathrm{ml})$, in contact with the pulpal side of the dentin contains the culture medium. The dentin bonding agents were applied the coronal side of the dentin slices following the recommendations of the manufacturers. A pulsatile pulpal pressure $\left(15 \mathrm{~cm} \mathrm{H} \mathrm{H}_{2} 0\right)$ was applied, as described. ${ }^{31}$ The dentin slices were inserted in the Plexiglas device for $24 \mathrm{~h}$, as described. ${ }^{30}$

In this work, the effect of One-Step (Bisco Dental Products, Itasca, IL, USA), Scotchbond One (3M Dental Products, St Paul, MN, USA), Prime and Bond NT (Dentsply DeTrey, Konstanz, Germany), Unibond (Septodont, Saint-Maur Des Fosses, France) (10 dentin slices for each) were studied. The bonding agents were applied and photopolymerized according to the manufacturers' instructions. The main monomers of the dentin bonding agents are given in Table 1.

A preliminary study of the succinic dehydrogenase activity of pulp fibroblasts with the MTT test
Table 1 Main monomers of the dentin bonding agents used in this study.

\begin{tabular}{lll} 
Product & Company & Main monomers \\
\hline One-Step & Bisco & Bis-GMA, BPDM, HEMA \\
Scotchbond One & 3 M & Bis-GMA, HEMA, TEGDMA \\
Prime and Bond NT & Dentsply & UDMA \\
Unibond & Septodont & HEMA, TEDMA
\end{tabular}

Bisco Dental Products, Itasca, IL, USA; 3M Dental Products, St Paul, MN, USA; Dentsply DeTrey, Konstanz, Germany; Septodont, Saint-Maur Des Fosses, France. Bis-GMA, bisphenol-glycidyl methacrylate; BPDM, bis-phenyl dimethacrylate; HEMA, hydroxyethyl methacrylate; UDMA, urethane dimethacrylate; TEGDMA, tri-ethylene glycol dimethacrylate; TEDMA, tri-ethylene dimethacrylate.

was performed as detailed previously. ${ }^{29-30}$ The cells cultured with the medium which remained in contact with the dentin slice (simulating the pulp chamber of the teeth) for $24 \mathrm{~h}$ was compared to that of fibroblasts cultured with control medium. This preliminary study was performed to select a non-toxic dilution of the media containing the compounds released through the dentin slice from the bonding agents. This dilution was selected in function of a decrease of $5-10 \%$ of the MTT activity. According to this preliminary study, the media were used after a dilution of $10 \%$.

Culture of dental pulp cells and bonding agent treatment. In this study, pulps of third molars were used. The culture procedure was performed as described previously. ${ }^{15,19}$

In order to evaluate the effect of bonding agents on the differentiation of pulp fibroblasts into odontoblasts, the cultured cells were incubated in the MEM medium supplemented with $2 \mathrm{mM}$ $\beta$-glycerophosphate (Sigma Chemical Co., St Louis, USA). Cells incubated with $\beta$-glycerophosphate were divided into two groups: with (test group) or without bonding agents (control group). In the test group, the cells were incubated with the culture medium containing non-toxic levels of one of the bonding agents. The medium was obtained from the device after being in contact with the pulpal side of the dentin slice for $24 \mathrm{~h}$. The cells were cultured for 4 weeks and the culture medium containing the bonding agents was changed every other day. After culture, the cells were fixed with $70 \%$ ethanol for $1 \mathrm{~h}$ at $4{ }^{\circ} \mathrm{C}$ and processed for immunohistochemistry. The effect of the bonding agents on the cytodifferentiation was evaluated by studying the specific protein expression of control cells compared to that of cells cultured with the media containing non-toxic dilutions of the bonding agents. The expression level of the proteins was evaluated qualitatively by two independent 
operators. Expression level was quite strong when it was equivalent to the control, and very strong when it was higher than the control.

Immunohistochemistry. The cells were permeabilized for $15 \mathrm{~min}$ with $0.5 \%$ Triton X-100 in PBS. Primary antibodies were diluted in PBS containing $0.1 \%$ bovine serum albumin. Incubation with primary antibodies was performed overnight at $4{ }^{\circ} \mathrm{C}$ at the following concentrations: anti-collagen I antibodies were used at $40 \mu \mathrm{g} / \mathrm{ml}$, and anti-osteonectin at $50 \mu \mathrm{g} / \mathrm{ml}$. Anti-dentin sialoprotein antibody was diluted 1:200 in PBS while anti-nestin antibody was diluted 1:1500. Immunostaining was revealed using the labeled streptavidin-biotin kit (LSAB; Dako Corporation, Carpinteria, CA, USA) according to the manufacturer's instructions. Glycergel was used as a mounting medium (Dako Corporation, Carpinteria, CA). Controls were performed by incubations with unrelated primary antibodies.

\section{Results}

\section{Human cultured dental pulp cells}

Human pulp cells grow in monolayers (Fig. 1A). However, after 2 weeks of $\beta$-glycerophosphate treatment, the cells acquired a multi-layered appearance at some areas which are the sites of appearance of newly formed mineral nodules (Fig. 1B).

Cells growing in a multi-layered fashion at the sites of appearance of the mineral nodules express a high level of type I collagen, osteonectin, dentin sialoprotein and nestin. Moreover, except for nestin, the expression of these proteins was also

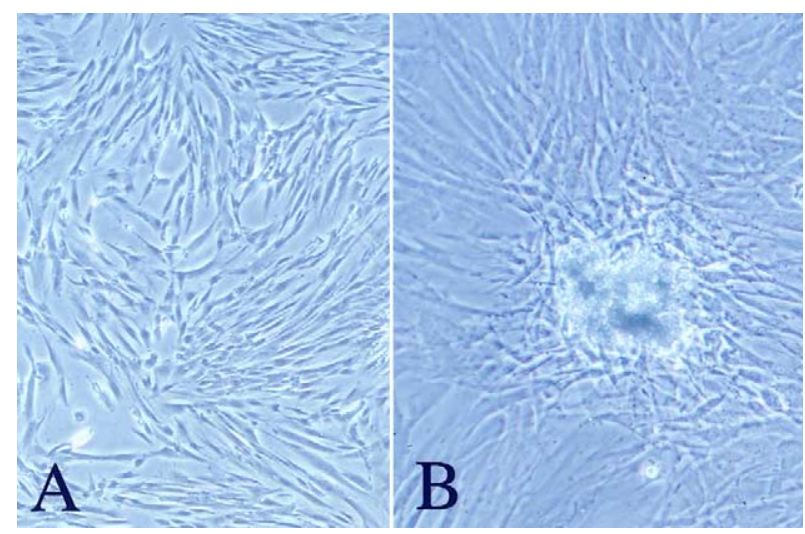

Figure 1 Control cultures of human pulp fibroblasts. Human pulp fibroblasts were cultured for 4 weeks in the absence or presence of $\beta$-glycerophosphate. Note that cells grow in monolayer cultures without $\beta$-glycerophosphate (A) and they grow as multilayers at the sites of mineral nodule formation (B).

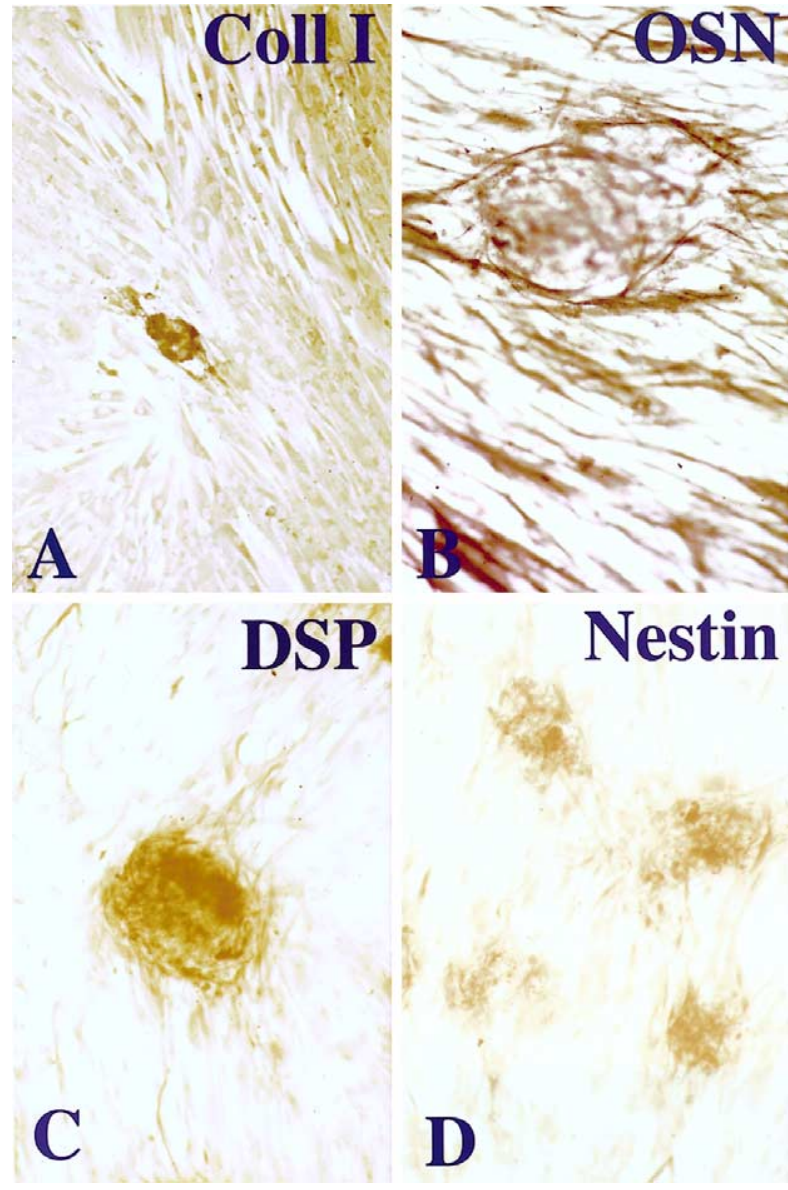

Figure 2 Odontoblast specific genes expression in control cultures of human pulp fibroblasts in the presence of $\beta$-glycerophosphate. Immunohistochemistry was used to demonstrate the odontoblastic specific genes expression in pulp cells cultured for 4 weeks in the presence of $\beta$-glycerophosphate. Collagen I (A), osteonectin (B) and dentin sialoprotein $(C)$ are expressed in dental pulp cells and in mineral nodules. Note that expression of osteonectin and dentin sialoprotein is strong in the nodules and cells forming the nodules. Nestin is also expressed in the cells and its expression is stronger in the mineral nodules forming cells (D). Original magnifications, $\times 10$.

evident in the mineral nodules. The immunostaining intensity was higher in cells forming the mineral nodules than the cells away from these nodules (Fig. 2).

\section{Effects of bonding agents on the dental pulp cells differentiation}

The study with the MTT test (Fig. 3) showed that the media obtained through the dentin slices were toxic when they were tested undiluted or when diluted to 50 or $20 \%$. They were non-toxic when they were diluted to 10 or to $1 \%$. A decrease of less than $10 \%$ of the MTT was considered as non-toxic. The dilution of $10 \%$ was chosen as non-toxic dilution for the rest 
Decrease of MTT activity (\%)

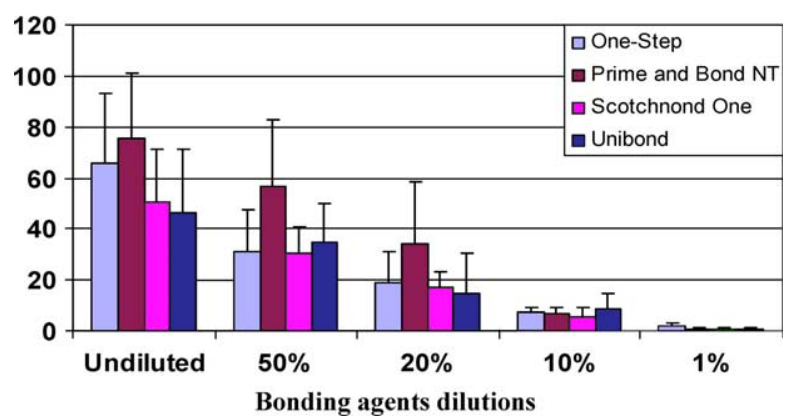

Figure 3 Decrease in MTT activity as a function of bonding agents dilutions. Bonding agents were applied on the coronal side of the dentin slices in Plexiglas devices with pulp pressure simulation. After $24 \mathrm{~h}$, the culture media in contact with the pulpal side of the dentin slices were used to measure the mitochondrial succinate dehydrogenase activity. The pulp fibroblasts were incubated with these media at different dilutions for $24 \mathrm{~h}$ before applying the MTT test.

of the study because the dilution of $1 \%$ had almost no effect on the MTT activity while the dilution to $10 \%$ decreased the MTT activity by $5-10 \%$.

After the addition of these media containing extracts of any of the bonding agents diluted to $10 \%$ to the cultured pulp cells, collagen I, osteonectin, dentin sialoprotein and nestin were strongly expressed by the differentiating cells (Fig. 4A-D, Table 2). Mineral nodule formation was also observed after treatment with all the bonding agents.

Collagen I and osteonectin showed an identical expression pattern with all the bonding agents. These proteins were expressed uniformly by the cells and in the mineral nodules (Fig. 4A-B, Table 2). DSP was strongly expressed in the cells as well as in the mineral nodules with all the bonding agents (Fig. 4C). Its expression was even very strong in the cells treated with One-Step and Prime and Bond (Table 2). Nestin was expressed by the cells but not in the mineral nodules and its expression was higher in the cells contacting the mineral nodules with all the bonding agents (Fig. 4D, Table 2). The immunostaining intensity was always higher in cells forming the mineral nodules than the cells away from these nodules (Fig. 4A-D). All controls where the cells were incubated with unrelated primary antibodies gave negative results.

\section{Discussion}

The evaluation of pulp health, with a pulp tester or with cold, before performing a restoration only gives approximate information, leading to a lack of

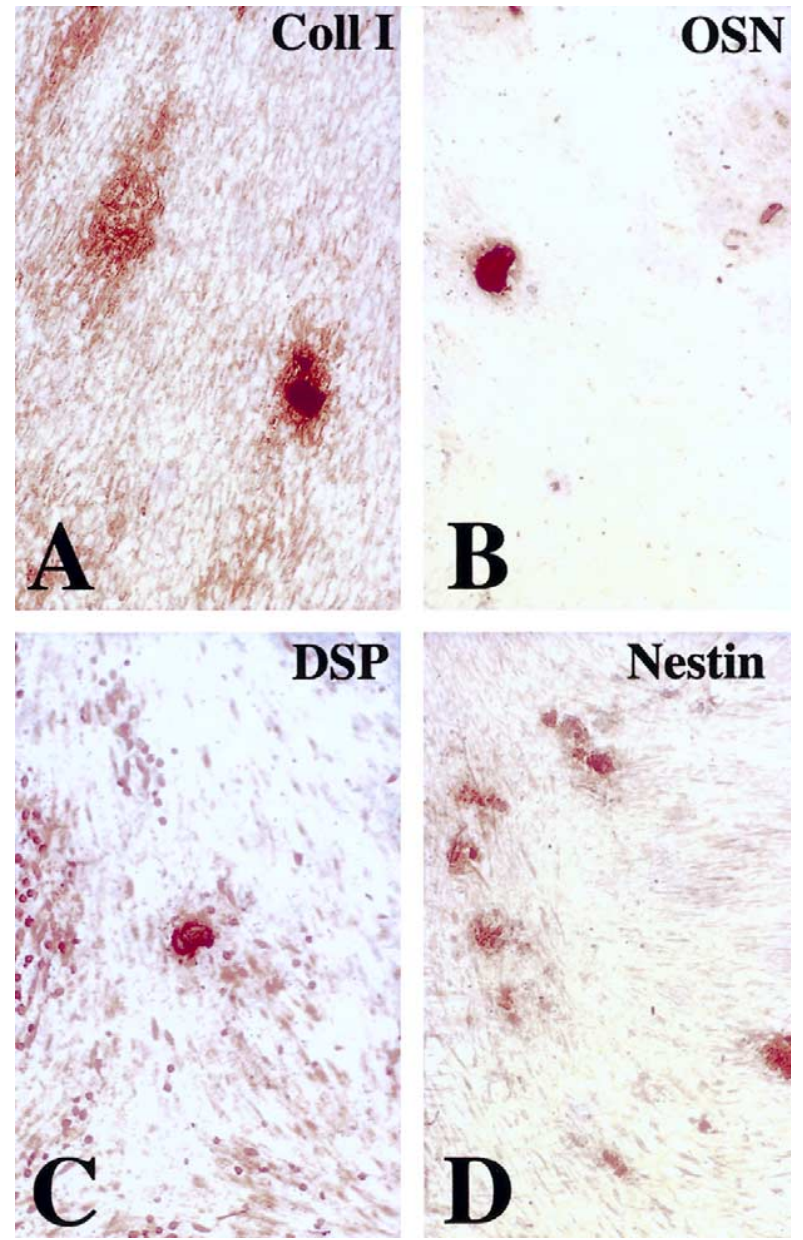

Figure 4 Effect of the bonding agents on pulp cells cytodifferation and specific genes expression in the presence of $\beta$-glycerophosphate. Immunohistochemistry was used to evaluate the effect of the bonding agents on pulp cells specific genes expression. Unibond is used here as an example to illustrate the effects of non-toxic dilutions of the bonding agents on specific genes expression. When Unibond was added to the culture medium for 4 weeks, collagen I (A), osteonectin (B) and dentin sialoprotein $(C)$ are expressed in dental pulp cells and in mineral nodules. Note that expression of osteonectin and dentin sialoprotein is strong in the nodules and cells forming the nodules. Nestin is also expressed in the cells and its expression is stronger in the mineral nodules forming cells (D). Original magnifications, $\times 10$.

correlation between the clinical symptoms and the real pulp state. ${ }^{32}$ Therefore, coronal restorations may be placed on teeth where the odontoblastic layer is partially destroyed, making the differentiation of secondary odontoblasts necessary prior to pulpal healing. Under these conditions, odontoblasts differentiate to allow the pulp to recover. If the diffusing uncured resinous monomers interfere with this critical step permitting pulp healing, the dead odontoblasts will be eliminated but not replaced. This has recently been described in 
Table 2 Expression level of collagen I, osteonectin, dentin sialoprotein and nestin after cells treatment with the bonding agents.

One-Step Prime and Bond NT Scotchbond Unibond

\begin{tabular}{|c|c|c|c|}
\hline Coll I & ++ & ++ & ++ \\
\hline OSN & ++ & ++ & ++ \\
\hline DSP & +++ & +++ & ++ \\
\hline Nestin & ++ & ++ & ++ \\
\hline
\end{tabular}

$++=$ Strong expression $=$ equivalent to the control; $+++=$ very strong expression $=$ higher than the control. Qualitative immunohistochemical evaluation of the effect of bonding agents on pulp cells cytodifferation and specific gene expression in the presence of $\beta$-glycerophosphate. After the addition of the media containing non-toxic dilutions of any of the bonding agents to the pulp cell cultures for 4 weeks, collagen I, osteonectin, dentin sialoprotein and nestin were strongly expressed by the differentiating cells.

a histological study. ${ }^{5}$ Dentin permeability associated to pulp clearance greatly reduced the biological effects of uncured monomers, limiting their pulpal concentrations. The role of dentin is demonstrated by the decrease of cytotoxicity, by several orders of magnitude when the cytotoxicity of dentin bonding agents is tested through dentin slices. ${ }^{29}$ However, even at low concentrations, the monomers may have biological effects. ${ }^{19-21}$ That is why the authors tested the hypothesis that non-toxic concentrations of photopolymerized dentin bonding agents may abolish the negative effects of the monomers on the differentiation of human pulp cells into odontoblasts. Under the conditions of this study, non-toxic concentrations of photopolymerized bonding agents used on dentin slices do not seem to interfere with the cytodifferentiation of secondary odontoblasts.

Dentin slices were interposed between the bonding agents and the culture medium to simulate the clinical conditions as well as to use the materials according to the manufacturers' instructions. The concentration of the molecules leached in the culture medium depends on the dentin thickness and permeability as well as the lower chamber volume. However, these factors do not modify the outcome of the main study as the authors worked with media dilutions determined from biological effects through the preliminary study of the MTT activity. A $10 \%$ dilution was chosen because it was the highest dilution with biological effects on MTT activity without being cytotoxic: dilutions to $20 \%$ were cytotoxic while a dilution to $1 \%$ had almost no biological effects as measured by the MTT assay. This study assumed that using thinner dentin slices or a smaller lower chamber volume would increase the bonding agents' effects on MTT activity depression.
Consequently this would have led the authors to adjust the media dilutions, without affecting the outcome of this study.

In this work, cells were used that are under the influence of dental restorative materials in vivo and specific functions of these cells studied. In a previous work, the authors have shown that these pulp cells cultured with $\beta$-glycerophoshate secrete an extracellular matrix deposit which progressively forms nodules of mineralized material. The FTIR analysis showed that it was not a non-specific deposition but that it had the same mineral composition as dentin. ${ }^{15}$ The cultured cells, particularly those involved in mineral nodule formation, express a high level of alkaline phosphatase activity indicating a high mineralization potential of these cells. Immunohistochemistry revealed that the type I collagen and osteonectin were highly expressed in these nodules. In addition, the cells express DSP. This protein which is expressed during human tooth development was also expressed in the nodules and its expression was stronger in the nodule-forming cells. ${ }^{19,23,33-34}$ DSP which is a $53-\mathrm{kDa}$ glycoprotein accounts for $5-8 \%$ of the dentin extracellular matrix, is localized mainly in dental tissues and its expression was reported to be localized and confined to differentiating odontoblasts, with a transient expression in the presecretory ameloblasts. ${ }^{24}$ However, odontoblasts express DSP to a much greater extent than other cell types. ${ }^{35}$ Moreover, nestin, a human odontoblast specific protein was expressed in these cells with a stronger expression in the cells contacting the mineral nodules. ${ }^{15,28}$

In a previous study, it was shown that when the resinous monomers were added to the culture medium, they differentially affected these proteins expression by the pulp cells. The effects of HEMA and Bis-GMA on collagen-1, osteonectin and DSP expression were more evident than those of TEGDMA and UDMA. However, all monomers significantly decreased DSP expression and completely inhibited the mineral nodule formation. Since DSP is involved in mineralization, the significant decrease or absence of DSP secretion may explain the complete inhibition of mineral nodules by the resinous monomers. ${ }^{19}$ This is an interesting aspect of the effects of resinous monomers on their target cells because the resinous monomers are cytotoxic at high concentrations but when they were used at low concentrations, they seemed to provoke specific effects on pulp cells.

The results of the authors' previous study compared to those of the current work clearly show that uncured monomers affect odontoblast differentiation while the photopolymerization of these monomers, associated to the interposition of 
dentin, seem to completely abolish the negative effects of the monomers. This is demonstrated in this work with four different bonding agents. After photopolymerization of these bonding agents, the cells incubated with the media containing the extracts of the bonding agents, expressed all the proteins studied here. Particularly, DSP, which is involved in the initiation and regulation of mineralization as well as nestin: the human odontoblast specific protein. Moreover, the cells secreted a mineralized extracellular matrix. In this matrix, a high level of Coll I, OSN, and DSP were found at the same level as in the control cultures.

The results of this work demonstrate that the biological effects of the composites depend on their use. On the one hand, this study concluded that dentin bonding agents do not affect the cytodifferentiation of secondary odontoblasts when the remaining dentin thickness is $0.7 \mathrm{~mm}$ and when they are properly polymerized. On the other hand, the authors' previous study showed that the direct contact of uncured monomers affected the differentiation of odontoblasts from pulp fibroblasts and the process of mineralization. In this present study, only one curing device was used, but this work emphasizes the importance of correct photopolymerization. Contradictory results have been reported regarding direct bonding of resins onto the pulp core showing that this technique can be material dependent. ${ }^{36}$ It has been suggested that acidic agents and adhesive resins should be avoided in vital pulp therapy ${ }^{18}$ as pulp repair was not obtained even 60 days, after All Bond 2 application onto dental pulp. ${ }^{37}$ On the contrary Cox et al. ${ }^{17}$ proposed to transfer their histological findings to clinics and to perform vital pulp therapy with resins. They reported that odontoblast differentiation was possible with various resins applied onto pulp core due to proper control of hemorrhage providing a stable interface for differentiation. ${ }^{17}$ The results of this work, under the light of the authors' previous study, indicate that the origin of these contradictions may lie in the degree of polymerization. The inhibition of cytodifferentiation observed in the first study was due to the monomers only, while none of the four dentin bonding agents displayed any effect on the same process when polymerized.

\section{Acknowledgements}

This work was supported by institutional grants from the French Ministry of Research and Education.

\section{References}

1. Pashley DH. Dynamics of the pulp-dentin complex. Crit Rev Oral Biol Med 1996;7:104-33.

2. Smith AJ, Tobias RS, Cassidy N, Plant CG, Browne RM, Bègue-Kirn C. Odontoblast stimulation in ferrets by dentine matrix components. Arch Oral Biol 1994;39:13-22.

3. Gerzina TM, Hume WR. Diffusion of monomers from bonding resin-resin composite combinations through dentin in vitro. J Dent 1996;24:125-8.

4. Bergenholz G, Cox C, Loeshe W, Syed S. Bacterial leakage around dental restorations: its effect on the dental pulp. J Oral Pathol 1982;11:439-50.

5. Camps J, Dejou J, Remusat M, About I. Factors influencing pulpal response to cavity restorations. Dent Mater 2000; 16(6):432-40.

6. Hanks CT, Strawn SE, Wataha JC, Craig RG. Cytotoxic effects of resin components on cultured mammalian fibroblasts. J Dent Res 1991;70:1450-5.

7. Ratanasathien S, Wataha J, Hanks CT, Dennison JB. Cytotoxic interactive effects of dentin bonding components on mouse fibroblasts. J Dent Res 1995;74:1602-6.

8. Rakich DR, Wataha JC, Lefebvre CA, Weller RN. Effects of dentin bonding agents on macrophages mitochondrial activity. J Endodon 1998;24:528-31.

9. Rakich DR, Wataha JC, Lefebvre CA, Weller RN. Effect of dentin bonding agents on the secretion of inflammatory mediators from macrophages. J Endodon 1999;25:114-7.

10. Jontell M, Hanks CT, Bratel J, Bergenholtz G. Effects of unpolymerized resin components on the function of accessory cells derived from the rat incisor pulp. J Dent Res 1995; 74:1162-7.

11. Payne MS, Horbett TA. Complement activation by hydroxyethylmethacrylate-ethylmethacrylate copolymers. $J$ Biomed Mater Res 1987;21:843-59.

12. Lesot H, Bègue-Kirn C, Kubler MD, Meyer JM, Smith AJ, Cassidy N, Ruch JV. Experimental induction of odontoblast differentiation and stimulation during reparative processes. Cells Mater 1993;3:201-17.

13. Rutherford $B$, Fitzgerald $M$. A new biological approach to vital pulp therapy. Crit Rev Oral Biol Med 1995;6:218-29.

14. Tziafas D, Smith AJ, Lesot $H$. Designing new treatment strategies in vital pulp therapy. J Dent 2000;28: 77-92.

15. About I, Bottero M-J, de Denato P, Camps J, Franquin J-C, Mitsiadis TA. Human dentin production in vitro. Exp Cell Res 2000;258:33-41.

16. Hosrted Bindlsev $P$, Lovschall H. Treatment outcome of vital pulp treatment. Endod Top 2002;2:24-34.

17. Cox CF, Suzuki S, Suzuki SH, Cox LK. Histological evaluation of direct pulp capping with various adhesive systems. In: Proceedings of the International Conference on Dentin/Pulp Complex 1995 and The International Meeting on Clinical Topics of Dentin/Pulp Complex, Tokyo: Quintessence International; 1996. p. 209-16.

18. De Souza-Costa CA, Hebling J, Hanks CT. Current status of pulp capping with dentin adhesive systems. Dent Mater 2000;16:188-97.

19. About I, Camps J, Mitsiadis TA, Butler WT, Franquin J-C. Influence of resinous monomers on the differentiation in vitro of human pulp cells into odontoblasts. $J$ Biomed Mater Res: Appl Biomater 2002;63:418-23.

20. Bouillaguet S, Wataha JC, Virgillito M, Gonzalez L, Rakich DR, Meyer JM. Effect of sub-lethal concentrations of HEMA (2-hydroxyethylmethacrylate) on THP-1 human monocytemacrophages, in vitro. Dent Mater 2000;16:213-7. 
21. Schuster GS, Caughman GB, Rueggeberg FA. Changes in cell phospholipid metabolism in vitro in the presence of HEMA and its degradation products. Dent Mater 2000;16: 297-302.

22. Butler WT, Ritchie $\mathrm{H}$. The nature and functional significance of dentin extracellular matrix proteins. Int J Dev Biol 1995; 39:169-79.

23. Ritchie HH, Hou H, Veis A, Butler WT. Cloning and sequence determination of rat dentin sialoprotein, a novel dentin protein. J Biol Chem 1994;269:3698-702.

24. Butler WT, Bhown M, D'Souza RN, Farach-Carson MC, Happonen R-P, Schrohenloher RE, Seyer JM, Somerman MJ, Foster RA, Tomana M, Van Dijk S. Isolation, characterization and immunolocalization of a $53-\mathrm{kDa}$ dentin sialoprotein. Matrix 1992;12:343-51.

25. Sjöberg G, Edström L, Lendahl U, Sejersen T. Myofibers from Duchenne/Becker muscular dystrophy and myositis express the intermediate filament nestin. J Neuropathol Exp Neurol 1994;53:416-23.

26. Sejersen T, Lendahl U. Transient expression of the intermediate filament nestin during skeletal muscle develop ment. J Cell Sci 1993;106:1291-300.

27. Dahlstrand J, Collins PV, Lendahl U. Expression of the class VI intermediate filament nestin in human central nervous system tumors. Cancer Res 1992;52:5334-41.

28. About I, Maquin D, Lendahl U, Mitsiadis TA. Expression of nestin in human teeth. Am J Pathol 2000;157(1):287-95.

29. Abou Hashieh I, Franquin JC, Cosset A, Dejou J, Camps J. Relationship between hydraulic conductance and the cytotoxicity of four dentin bonding resins in vitro. J Dent 1998;26:473-7.

30. Abou Hashieh I, Camps J, Dejou J, Franquin J-C. Eugenol diffusion through dentin related to dentin hydraulic conductance. Dent Mater 1998;14:229-36.

31. Camps J, Tardieu C, Dejou J, Franquin JC, Ladaique P, Rieu R. In vitro cytotoxicity of dental adhesive systems under simulated pulpal pressure. Dent Mater 1997;13:34-42.

32. Lundy T, Stanley HR. Correlation of pulpal histology and clinical symptoms in human teeth subjected to experimental irritation. Oral Med Oral Surg Oral Pathol 1969;27:187-201.

33. Reichert T, Störkel S, Becker K, Fisher LW. The role of osteonectin in human tooth development: an immunohistochemical study. Calcif Tissue Int 1992;50:468-72.

34. Shiba H, Nakamura S, Shirakawa M, Nakanishi K, Okamoto H, Satakeda $\mathrm{H}$, Noshiro M, Kamihagi K, Katayama M, Kato $\mathrm{Y}$. Effects of basic fibroblast growth factor on proliferation, the expression of osteonectin (SPARC) and alkaline phosphatase, and calcification in cultures of human pulp cells. Dev Biol 1995; 170:457-66.

35. Qin C, Brunn JC, Cadena E, Ridall A, Tsujigiwa H, Nagatsuka $\mathrm{H}$, Nagai N, Butler WT. The expression of dentin sialophosphoprotein gene in bone. J Dent Res 2002;81:392-4.

36. Kitasako Y, Inokoshi S, Tagami J. Effects of direct resin pulp capping techniques on short-term response of mechanically exposed pulps. J Dent 1999;27:257-63.

37. Hebling J, Giro EM, Costa CA. Biocompatibility of an adhesive system applied to exposed human dental pulp. J Endodon 1999;25:676-82. 